\title{
The effect of astaxanthin on resistance of juvenile prawns Macrobrachium nipponense (Decapoda: Palaemonidae) to physical and chemical stress
}

\author{
Babak Tizkar ${ }^{1}$, Alireza Seidavi $^{2}$, Jesús Trinidad Ponce-Palafox ${ }^{3 *} \&$ Parastoo Pourashoori $^{4}$ \\ 1. Mirza Koochak Khan Higher Fisheries Centre, University of Jame-e Elmi- Karbordi, Rasht, Iran; btizkar@yahoo.com \\ 2. Animal Science Department, Rasht Branch, Islamic Azad University, Rasht, Iran; alirezaseidavi@iaurasht.ac.ir \\ 3. Centro Multidisciplinario de Bahía de Banderas, Escuela Nacional de Ingeniería Pesquera, Lab. Bioingeniería \\ Costera, Universidad Autónoma de Nayarit, Tepic. 63155. Nayarit, México; jesus.ponce@usa.net \\ 4. Fishery Department, Gorgan University of Agricultural Science and Natural Resources, Gorgan, Iran; \\ parastoo1980@yahoo.com \\ * Correspondence
}

Received 20-I-2014. Corrected 25-V-2014. Accepted 26-VI-2014.

\begin{abstract}
In recent years, the use of new scientific techniques has effectively improved aquaculture production processes. Astaxanthin has various properties in aquaculture and its antioxidant benefits have been closely related to stress resistance; besides, it is an essential factor for growth in many crustaceans and fish. The objective of this study was to evaluate the resistance of prawn (Macrobrachium nipponense) fed diets containing different amounts of astaxanthin (AX) to the shock and stress of different physicochemical environments. A 70-day trial was conducted to evaluate the effect of supplementation of a source of astaxanthin (Carophyll Pink, $10 \%$ astaxanthin, w/w, Hoffman-La Roche, Switzerland) at various levels in the diet of M. nipponense juveniles. Four dry diets were prepared: $\mathrm{AX}_{0}$ without astaxanthin, $\mathrm{AX}_{50}$ with $50 \mathrm{mg} / \mathrm{kg}, \mathrm{AX}_{100}$ with $100 \mathrm{mg} / \mathrm{kg}$, and $\mathrm{AX}_{150}$ with $150 \mathrm{mg} / \mathrm{kg}$ astaxanthin. The feeding trial was conducted in a recirculation water system consisting of 12 fiberglass tanks (1000L) used for holding prawns. Three replicate aquaria were initially stocked with 36org/ $\mathrm{m}^{2}$ per tank. During the trial, prawns were maintained on a 12:12-h light:dark photoperiod with an ordinary incandescent lamp, and the water quality parameters were maintained as follows: water temperature, $25-26^{\circ} \mathrm{C}$; salinity, $1 \mathrm{~g} / \mathrm{L} ; \mathrm{pH}, 8.5-8.8$; dissolved oxygen, $6.0-6.5 \mathrm{mg} / \mathrm{L}$; and ammonia-nitrogen, $0.05 \mathrm{mg} / \mathrm{L}$. Incorporation of AX, production output, and physiological condition were recorded after 10 weeks of feeding. At the end of the growing period, the prawns were exposed to thermal shock $\left(0^{\circ} \mathrm{C}\right)$, ammonia $(0.75 \mathrm{mg} / \mathrm{L})$, and reduced oxygen $(0.5 \mathrm{mg} / \mathrm{L})$. The time to lethargy and the time to complete death of the prawns were recorded. The results showed that control prawns had the shortest time to lethargy and death compared with prawns subjected to the other treatments. The results of this study have shown that the amount of muscle tissue and gill carotenoids in prawn fed with an $\mathrm{AX}_{150}$ diet showed greater reduction than those exposed to other treatments. It is possible that higher levels of astaxanthin in the body under oxygen reduction stress can be beneficial for prawns. These results suggest that male prawns showed lethargy earlier than females, and the percentage of carotenoid reduction in muscle and gill tissues was higher in males. Rev. Biol. Trop. 62 (4): 1331-1341. Epub 2014 December 01.
\end{abstract}

Key words: ammonia, astaxanthin, prawn, stress, thermal.

In recent years, the use of new scientific techniques has effectively improved aquaculture production processes. Carotenoids are colored pigments found in plant and animal products; however, only plants, some bacteria, and yeasts are able to produce carotenoids. The colored pigments can enter (and accumulate within) the bodies of crustaceans through the food chain (Ponce-Palafox, ArredondoFigueroa, \& Vernon-Carter, 2006).

Carotenoids play very important roles in human and animal health (Yuan, Peng, Yin, \& Wang, 2011). They act as potent antioxidants that inactivate oxygen free radicals produced by normal cellular activities or free radicals released by stressors (Chew, 1995). 
Similar to other animals, crustaceans cannot make carotenoids, which are needed for their metabolic processes. Thus, in the natural environment, crustaceans must obtain carotenoids from their diet; similarly, in a cultured environment, carotenoids must also be added to the diet (Hornero-Mendez \& Britton, 2002). Beta-carotene is known as an antioxidant for fats, and astaxanthin, which has a long chain with a double bond and unstable electron orbitals, can be used to protect against oxygen radicals within cells (Stanier, Kunizawa, \& Cohen-Bazire, 1971). The antioxidant activity of astaxanthin is known to be 10 times higher than that of beta-carotene and 100 times higher than that of alpha-tocopherol (Shimidzu, Goto, \& Miki, 1996). Thus, astaxanthin is sometimes referred to as "super vitamin E" (Miki, 1991).

Astaxanthin has various properties in aquaculture (Torrissen, 1990; Shimidzu et al., 1996), and its antioxidant properties are closely related to stress resistance. Resistance against salinity stress (Darachai, Piyatiratitivorakul, Kittakoop, Nitithamyong, \& Menasveta, 1998; Merchie et al., 1998; Chien, Pan, \& Hunter, 2003), thermal stress (Chien et al., 2003), and stress-induced oxygen reduction (evacuated oxygen) (Chien et al., 2003) are known to be conferred by astaxanthin. Torrissen and Christiansen (1995) indicated that astaxanthin in many crustaceans and fish is an essential factor for growth, and other carotenoids, such as canthaxanthin, beta-carotene, xanthophylls, and lutein, may also have important physiological functions in the cell.

As previously noted, some researchers believe that under conditions of oxygen deficiency, carotenoids may play an important role in respiration of the ovule. Craik and Harvey (1984) showed that carotenoids in eggs had roles in respiration. Similarly, they found that broodstock that were fed diets containing carotenoids had eggs with greater amounts of carotenoids, and the state of over-maturity occurred later in this group than in the control group. Chien, Chen, Pan, and Kurmaly (1999) found that juvenile shrimp fed a diet containing a high level of astaxanthin showed increased survival compared with control animals under oxygen depletion stress (dissolved oxygen [DO], $<1 \mathrm{mg} / \mathrm{L}$ for $4 \mathrm{~h}$ ). Some studies have shown that one of the main functions of carotenoids is to counter the toxicity of ammonia and other toxic amines produced by protein metabolism (Pan, Chien, \& Hunter, 2003). The highly colored eggs of Oncorhynchus kisutch are more highly resistant to the increase in ammonia compared with pale rainbow trout eggs (Yarzhombek, 1970). Studies exploring the ability of antioxidants to protect against oxidative damage can be conducted by pretreating animals with antioxidants and subjecting them to oxidative stress induced by oxidants or toxic substances (Aispuro-Hernandez et al., 2008). Pan et al. (2003) tested the antioxidant effects of astaxanthin in shrimp juveniles in terms of recovery, aspartate aminotransferase level, and alanine aminotransferase level under thermal and osmotic stress. The objective of this study was to evaluate the resistance of shrimp (Macrobrachium nipponense) that were fed diets containing different amounts of astaxanthin to different physical and chemical changes inducing stress.

\section{MATERIALS AND METHODS}

A 70-day trial was conducted to evaluate the effect of supplementation of a source of astaxanthin (Carophyll Pink, 10\% astaxanthin, w/w, Hoffman-La Roche, Switzerland) at various levels in the diet of $M$. nipponense juveniles. Four dry diets were prepared: $\mathrm{AX}_{0}$ without astaxanthin, $\mathrm{AX}_{50}$ with $50 \mathrm{mg} / \mathrm{kg}$, $\mathrm{AX}_{100}$ with $100 \mathrm{mg} / \mathrm{kg}$, and $\mathrm{AX}_{150}$ with $150 \mathrm{mg} /$ $\mathrm{kg}$ astaxanthin (Table 1). The food was mixed and homogenized and subsequently converted to pellets ( $3 \mathrm{~mm}$ diameter) using a California Pelleting Machine (CPM); it was steamed for $6 \mathrm{~min}$ and dried at a temperature of $45^{\circ} \mathrm{C}$ for $3 \mathrm{~h}$. All the diets were stored at $-18^{\circ} \mathrm{C}$ until use. Crude protein, total fat, carbohydrate, ash, and moisture were measured using the method described by Association of Analytical Chemists (AOAC, 2005) (Table 2). At the end of the growing period, three stressor 
TABLE 1

Ingredients and composition of experimental diets*

\begin{tabular}{|c|c|c|c|c|}
\hline Ingredients & $\mathrm{AX}_{0}$ & $\mathrm{AX}_{50}$ & $\mathrm{AX}_{100}$ & $\mathrm{AX}_{150}$ \\
\hline Fish meal & 30.0 & 30.0 & 30.0 & 30.0 \\
\hline Wheat meal & 8.0 & 8.0 & 8.0 & 8.0 \\
\hline Rice bran & 4.0 & 4.0 & 4.0 & 4.0 \\
\hline Wheat bran & 11.0 & 10.9 & 10.9 & 10.8 \\
\hline Soybean meal & 21.5 & 21.5 & 21.5 & 21.5 \\
\hline Corn & 10.0 & 10.0 & 10.0 & 10.0 \\
\hline Starch & 0.5 & 0.5 & 0.5 & 0.5 \\
\hline Barley meal & 12.0 & 12.0 & 12.0 & 12.0 \\
\hline Astaxanthin ${ }^{1}$ & 0.0 & 0.05 & 0.1 & 0.15 \\
\hline Di-calcium Phosphate & 1.0 & 1.0 & 1.0 & 1.0 \\
\hline Mineral mixture ${ }^{2}$ & 1.0 & 1.0 & 1.0 & 1.0 \\
\hline Vitamin mixture ${ }^{3}$ & 1.0 & 1.0 & 1.0 & 1.0 \\
\hline Total & 100.0 & 100.0 & 100.0 & 100.0 \\
\hline
\end{tabular}

1. Chlorophyll pink contains $10 \%$ active form of astaxanthin, Roche.

2. Mineral mixture $100 \mathrm{~g}$ contains: $\mathrm{K}_{2} \mathrm{HPO}_{4} 2.0 \mathrm{~g}$, $\mathrm{Ca}_{3}\left(\mathrm{PO}_{4}\right)_{2} 2.720 \mathrm{~g}, \mathrm{MgSO}_{4} 7 \mathrm{H}_{2} \mathrm{O}, 3.041 \mathrm{~g}, \mathrm{NaH}_{2} \mathrm{PO}_{4}$ $2 \mathrm{H} 2 \mathrm{O} 0.790 \mathrm{~g}$.

3. Vitamin mixture $10 \mathrm{~g}$ contains: $\rho$-aminobenzoic acid $10.0 \mathrm{mg}$; biotin $0.40 \mathrm{mg}$, inositol $400.0 \mathrm{mg}$; nicotinic acid, 40.0mg; Ca-pantothenate, $60.0 \mathrm{mg}$; pyridoxine$\mathrm{HCl}$, 12.0mg; riboflavin, $8.0 \mathrm{mg}$; thiamin- $\mathrm{HCl}, 4.0 \mathrm{mg}$; menadione, $4.0 \mathrm{mg}$; cyanocobalamine, $0.08 \mathrm{mg}$; calciferol, $1.20 \mathrm{mg}$; folic acid, $0.80 \mathrm{mg}$; choline chloride, $120.0 \mathrm{mg}$.

* (g 100/g dry wt).

experiments were performed on treatment and control shrimp and on males and females separately. The amount of total carotenoids in the gill area and trunk muscles was measured at the beginning and end of the experiment (Chien et al., 2003).
The feeding trial was conducted in 12 fiberglass tanks (1 000L) used for holding prawns. The tanks were maintained by a continuous recirculation system (2\%) via a $3 / 4 \mathrm{Hp}$ pump (Siemens) that generated a daily turnover volume of 200\%; a 1/3 Hp blower (Pioneer, RB20510, Ling-Ya, Kaohsiung, Taiwan) aerated the water, and a sand filter provided mechanical filtration. Three replicate aquaria were initially stocked with $360 \mathrm{rg} / \mathrm{m}^{2}$ per tank. During the trial, prawns were maintained on a 12:12-h light:dark photoperiod with an ordinary incandescent lamp, and the water quality parameters were maintained as follows: water temperature, 25-26 ${ }^{\circ} \mathrm{C}$; salinity, $1 \mathrm{~g} / \mathrm{L}$; $\mathrm{pH}, 8.5-8.8$; dissolved oxygen, $6.0-6.5 \mathrm{mg} / \mathrm{L}$; and ammonia-nitrogen, $0.05 \mathrm{mg} / \mathrm{L}$. To keep the prawns within nests and decrease nest cannibalism, 10 clay nests were placed in each tank.

A total of 432 freshwater shrimp (M. nipponense) from the international Anzali wetland in Iran were collected. The females and males had average individual weights of $1.17 \pm 0.20 \mathrm{~g}$ and $2.78 \pm 0.34 \mathrm{~g}$, respectively. The prawns were fed the experimental diets three times daily (7:00, 13:00, and 19:00h). The feeding quantity was adjusted to $5 \%$ of their body weight per day. Feed, fecal waste, and prawn shells were removed daily through a siphon from the pond bottom.

At the end of the feeding trial, the prawns were fasted for $24 \mathrm{~h}$ and then weighed. After weighing, most prawns in each aquarium were used for samples, dried, and homogenized for whole body composition analysis. A $10 \mathrm{~g}$ feed

TABLE 2

Proximate analysis of experimental diets as fed basis*

\begin{tabular}{lcccc}
\multicolumn{1}{c}{ Item } & $\mathrm{AX}_{0}$ & $\mathrm{AX}_{50}$ & $\mathrm{AX}_{100}$ & $\mathrm{AX}_{150}$ \\
Crude protein & $38.7 \pm 1.2$ & $38.7 \pm 1.3$ & $38.6 \pm 1.3$ & $38.6 \pm 1.4$ \\
Crude fat & $8.4 \pm 0.3$ & $8.5 \pm 0.3$ & $8.4 \pm 0.3$ & $8.4 \pm 0.3$ \\
Moisture & $14.5 \pm 0.2$ & $14.5 \pm 0.1$ & $14.5 \pm 0.1$ & $14.5 \pm 0.1$ \\
Ash & $11.2 \pm 0.1$ & $11.1 \pm 0.1$ & $11.3 \pm 0.1$ & $11.2 \pm 0.1$ \\
Fiber & $2.5 \pm 0.0$ & $2.5 \pm 0.0$ & $2.5 \pm 0.0$ & $2.5 \pm 0.0$ \\
NFE & $11.3 \pm 1.2$ & $11.3 \pm 1.3$ & $11.2 \pm 1.3$ & $11.2 \pm 1.3$ \\
Total carotenoid $(\mathrm{mg} / \mathrm{kg})$ & $8.2 \pm 1.25$ & $28.35 \pm 3.25$ & $45.24 \pm 4.54$ & $68.89 \pm 5.25$ \\
\hline
\end{tabular}

* $(\mathrm{g} / 100 \mathrm{~g} ;$ mean \pm standard error $)$. 
sample was randomly removed from each diet and analyzed to determine its approximate composition. Moisture, crude protein, crude lipid, fiber, and ash contents of the experimental diets and prawns (triplicate samples) were determined using standard methods (AOAC, 2005). To determine the amount of total carotenoids extracted, UV-visible spectrophotometry (Hitachi, U-1800) was used with a spectral window between 380 and $750 \mathrm{~nm}$; triplicate samples were measured. The carotenoid concentration was obtained using the Lambert-Beer law, and for calculation purposes, the following equation was applied to the absorbance values:

Total carotenoid $\mu \mathrm{g} / \mathrm{mgh}=($ absorbance $/ €$ $\mathrm{x}$ molecular mass $\times 1,000 \times$ sample volume $\mathrm{L}) /$ sample dry weight $) \mathrm{mg}($.

The specific optical extinction coefficient $€^{1}{ }_{1 \mathrm{~cm}}$ of $124,000_{\text {(astaxanthin) }}$ at $460 \mathrm{~nm}$ was used (Buchwaldt \& Jencks, 1968) in conjunction with a molecular mass of 596.84 (astaxanthin). The absorbance measurements were performed in triplicate, and the values previously averaged were applied in the above equation (Schoefs, 2002).

Thermal shock experiments: In this experiment, 3 male and 3 female shrimp were selected from each replicate and immediately transferred in bottles of cold water to a temperature of $0^{\circ} \mathrm{C}$. At the time of transfer, the water temperature was $24^{\circ} \mathrm{C}$. For this purpose, 72 number one liter bottles containing cold water were prepared. Each shrimp was placed separately inside a bottle. During the experimental period, the amount of dissolved oxygen in the bottles was equal to $6.5 \pm 0.6 \mathrm{mg} / \mathrm{L}$, and the $\mathrm{pH}$ was $8.5 \pm 0.2$. The time to lethargy and time to complete death of the shrimp were recorded.

Ammonia shock experiments: In this experiment, 72 bottles of $1 \mathrm{~L}$ capacity were prepared and filled with water. Liquid ammonia $(0.75 \mathrm{mg} / \mathrm{L})$ was added to each bottle. Then, according to the previous experiment, one prawn was placed in each bottle. Time to lethargy and complete death was measured for the shrimp in each bottle. During the experimental period, the amount of dissolved oxygen in the bottles was equal to $6.5 \pm 0.6 \mathrm{mg} / \mathrm{L}$, and the $\mathrm{pH}$ was $8.5 \pm 0.4$.

Oxygen reduction shock experiments: In this experiment, 72 bottles of $1 \mathrm{~L}$ capacity were prepared and filled with water from the same water bath. Nitrogen gas was then injected into the bottles, and the dissolved oxygen in the bottles decreased to $0.5 \mathrm{mg} / \mathrm{L}$. At this time, prawns were added to the bottle, and time to lethargy and complete death of the prawn in each bottle were measured. During the experimental period, the $\mathrm{pH}$ was $8.5 \pm 0.4$ and the water temperature was $25.3 \pm 1.2^{\circ} \mathrm{C}$.

This study was designed based on a factorial design (Montgomery, 2005). The data were verified using the Kolmogorov-Smirnov Test, normalized, and subjected to two-way ANOVA. Tukey's test was used to compare differences between the diets. All data were examined at the $5 \%$ level, and the mean \pm standard error is presented.

\section{RESULTS}

Carotenoids in tissue: After 10 weeks of consuming diets $\mathrm{AX}_{50}, \mathrm{AX}_{100}$, and $\mathrm{AX}_{150}$, carotenoid levels were significantly (Tukey, $\mathrm{p}<0.05$ ) increased in muscle and gill tissues in males and females compared to carotenoid levels in animals that consumed the control diet. The average increases in male and female muscle tissues were $89.8 \pm 19.7 \%$ and $89.2 \pm 14.3 \%$, respectively. The average increases in the gills of males and females were $166.2 \pm 26.9 \%$ and $137.7 \pm 17.9 \%$, respectively (Table 3 ). The absorption of carotenoids in the muscle tissue of male and female prawns showed no significant differences (Tukey, $\mathrm{p}>0.05$ ); however, the carotenoid level in gills was significantly (Tukey, $\mathrm{p}<0.05$ ) higher in males.

Thermal shock experiments: The average time of lethargy in cold shock for male and female prawn showed significant differences (Tukey, $\mathrm{p}<0.05$ ). The shortest lethargy time was related to the control diet and the longest 
TABLE 3

Carotenoids increased in gills and muscle of $M$. nipponense after feeding astaxanthin*

\begin{tabular}{ccc} 
Treatment & $\begin{array}{c}\text { Carotenoid } \\
\text { Muscle Tissue }\end{array}$ & Carotenoid Gill \\
$\mathrm{AX}_{0}$ & $14.5 \pm 4.9^{\mathrm{d}}$ & $61.3 \pm 3.5^{\mathrm{d}}$ \\
$\mathrm{AX}_{50}$ & $65.2 \pm 6.5^{\mathrm{c}}$ & $107.3 \pm 6.7^{\mathrm{c}}$ \\
$\mathrm{AX}_{100}$ & $119.1 \pm 6.9^{\mathrm{b}}$ & $186.9 \pm 10.6^{\mathrm{b}}$ \\
$\mathrm{AX}_{150}$ & $159.1 \pm 10.9^{\mathrm{a}}$ & $252.3 \pm 16.7^{\mathrm{a}}$ \\
Male & $89.81 \pm 19.7^{\mathrm{a}}$ & $166.2 \pm 26.9^{\mathrm{a}}$ \\
Female & $89.20 \pm 14.3^{\mathrm{a}}$ & $137.7 \pm 17.9^{\mathrm{b}}$ \\
\hline
\end{tabular}

*(\%; mean \pm standard error $)$; Means in each semi-column followed by the same letters are not significantly different at $\mathrm{p}<0.05$.

lethargy times in the males and females were related to the $\mathrm{AX}_{100}$ and $\mathrm{AX}_{150}$ diets (Table 4).

The results indicated that the $\mathrm{AX}_{150}$ diet led to the latest complete death in shrimp (Table 4). The amount of carotenoids found in the body and gills was significantly reduced by the shocks that the prawn were exposed to during the experimental process. The average percent reduction in total carotenoids in the muscle tissue of males and females showed significant differences (Tukey, $\mathrm{p}<0.05$ ). However, despite a greater reduction in the carotenoid level in the gills of males, this value was not significantly different (Tukey, $\mathrm{p}>0.05$ ) compared with that observed in females (Table 4). The greatest percent reduction in carotenoid content in the muscle tissue of males and females was observed in those fed the $\mathrm{AX}_{150}$ diet, and the lowest percent reduction was observed in those fed the control diet. In the gills of males, the largest percentage decrease was observed in those fed the $\mathrm{AX}_{100}$ diet and the least reduction was observed in those fed the control diet. The maximum reduction in carotenoids in female gills was observed in those fed the $\mathrm{AX}_{150}$ diet, and the lowest reduction was observed in those fed the $\mathrm{AX}_{50}$ diet (Table 4).

Ammonia shock experiments: The average time of lethargy in the ammonia shock experiment was faster in males versus females (Tukey, $\mathrm{p}<0.05$ ). The shortest lethargy time in both males and females was observed with the control diet, and the longest lethargy time in both males and females was related to the

TABLE 4

Time (mean \pm standard error) of lethargy, complete death, and loss percentage of total carotenoid in gill and muscle tissues against thermal shock in M. nipponense*

\begin{tabular}{|c|c|c|c|c|c|}
\hline \multicolumn{2}{|c|}{$\begin{array}{c}\text { Treatment } \\
\text { (Astaxanthin kg Dried diet) }\end{array}$} & Lethargy (h) & Death (h) & $\begin{array}{l}\text { Loss percentage muscle } \\
\text { tissue carotenoid }\end{array}$ & $\begin{array}{l}\text { Loss percentage gill } \\
\text { carotenoid }\end{array}$ \\
\hline \multicolumn{2}{|r|}{$\mathrm{AX}_{0}$} & $13.9 \pm 0.4^{\mathrm{c}}$ & $18.4 \pm 0.4^{\mathrm{c}}$ & $13.1 \pm 1.9^{\mathrm{d}}$ & $38.5 \pm 0.9^{b}$ \\
\hline \multicolumn{2}{|r|}{$\mathrm{AX}_{50}$} & $19.1 \pm 0.2^{\mathrm{b}}$ & $23.9 \pm 0.4^{\mathrm{b}}$ & $35.4 \pm 1.4^{\mathrm{c}}$ & $41.4 \pm 0.9^{\mathrm{b}}$ \\
\hline \multicolumn{2}{|r|}{$\mathrm{AX}_{100}$} & $23.8 \pm 0.3^{\mathrm{a}}$ & $28.9 \pm 0.3^{\mathrm{a}}$ & $45.4 \pm 1.4^{\mathrm{b}}$ & $50.4 \pm 0.5^{\mathrm{a}}$ \\
\hline \multicolumn{2}{|r|}{$\mathrm{AX}_{150}$} & $24.3 \pm 0.4^{\mathrm{a}}$ & $29.1 \pm 0.6^{\mathrm{a}}$ & $51.6 \pm 1.5^{\mathrm{a}}$ & $53.8 \pm 0.8^{\mathrm{a}}$ \\
\hline \multicolumn{2}{|r|}{ Male } & $21.7 \pm 0.3^{\mathrm{a}}$ & $30.8 \pm 0.3^{\mathrm{a}}$ & $34.6 \pm 0.9^{\mathrm{b}}$ & $46.2 \pm 0.4^{\mathrm{a}}$ \\
\hline \multicolumn{2}{|r|}{ Female } & $18.8 \pm 0.3^{\mathrm{b}}$ & $19.4 \pm 0.4^{\mathrm{b}}$ & $38.2 \pm 1.0^{\mathrm{a}}$ & $45.8 \pm 0.5^{\mathrm{a}}$ \\
\hline \multirow{4}{*}{$\frac{0}{\sum^{\pi}}$} & $\mathrm{AX}_{0}$ & $15.6 \pm 0.7^{b}$ & $12.4 \pm 1.2^{\mathrm{d}}$ & $35.8 \pm 1.4^{\mathrm{d}}$ & $20.60 \pm 0.3^{b}$ \\
\hline & $\mathrm{AX}_{50}$ & $20.8 \pm 0.4^{b}$ & $31.2 \pm 2.3^{\mathrm{c}}$ & $44.19 \pm 1.57^{\mathrm{c}}$ & $30.67 \pm 0.1^{\mathrm{b}}$ \\
\hline & $\mathrm{AX}_{100}$ & $25.3 \pm 0.6^{\mathrm{a}}$ & $42.5 \pm 2.6^{\mathrm{b}}$ & $56.20 \pm 2.39^{\mathrm{b}}$ & $35.26 \pm 0.44^{\mathrm{a}}$ \\
\hline & $\mathrm{AX}_{150}$ & $25.3 \pm 0.6^{\mathrm{a}}$ & $52.3 \pm 2.5^{\mathrm{a}}$ & $48.78 \pm 1.32^{\mathrm{a}}$ & $36.81 \pm 0.59^{\mathrm{a}}$ \\
\hline \multirow{4}{*}{ 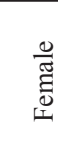 } & $\mathrm{AX}_{0}$ & $12.19 \pm 0.4^{\mathrm{c}}$ & $13.79 \pm 1.3^{\mathrm{c}}$ & $41.3 \pm 1.3^{b}$ & $16.3 \pm 0.6^{\mathrm{b}}$ \\
\hline & $\mathrm{AX}_{50}$ & $17.49 \pm 0.5^{\mathrm{b}}$ & $39.64 \pm 2.5^{\mathrm{b}}$ & $38.6 \pm 2.2^{\mathrm{b}}$ & $17.3 \pm 0.3^{b}$ \\
\hline & $\mathrm{AX}_{100}$ & $22.3 \pm 0.5^{\mathrm{a}}$ & $48.4 \pm 1.5^{\mathrm{a}}$ & $44.7 \pm 1.9^{b}$ & $22.6 \pm 0.2^{\mathrm{a}}$ \\
\hline & $\mathrm{AX}_{150}$ & $23.3 \pm 0.2^{\mathrm{a}}$ & $50.9 \pm 2.6^{\mathrm{a}}$ & $58.8 \pm 1.8^{\mathrm{a}}$ & $21.5 \pm 0.3^{\mathrm{a}}$ \\
\hline
\end{tabular}

*(\%; mean \pm standard error $)$; Means in each semi-column followed by the same letters are not significantly different at $\mathrm{p}<0.05$. 
$\mathrm{AX}_{150}$ diet (Table 5). The results indicate significant differences between the average time to complete death of male and female prawns due to ammonia shock (Tukey, $\mathrm{p}<0.05$ ). The male prawn died faster than the females. The latest complete death in both males and females was observed with the $\mathrm{AX}_{100}$ and $\mathrm{AX}_{150}$ diets, and the fastest time to complete death in both males and females was observed with the control diet (Table 5).

Ammonia shock also reduces the total amount of carotenoids in the muscle tissue and gills of prawns. Our results showed that the total amount of carotenoids was more greatly reduced in the muscle tissue of male versus female prawns (Table 5). The highest percentage reduction in carotenoids in male muscle tissue was observed in those fed the $\mathrm{AX}_{150}$ diet, and the lowest percentage reduction was observed in those fed the control diet; however, in females, the greatest percentage decrease in muscle carotenoids was observed in those fed the $\mathrm{AX}_{100}$ diet. In males, the largest percentage decrease in gill tissue was observed in those fed the $\mathrm{AX}_{150}$ diet, and the lowest decrease was observed in those fed the $\mathrm{AX}_{50}$ diet. A maximum reduction in carotenoids in female gill tissue was observed in those fed the $\mathrm{AX}_{150}$ diet, and the least reduction was observed in those fed the $\mathrm{AX}_{50}$ diet (Table 5).

Oxygen reduction shock experiments: Due to the hypo-oxygen shock effect, the male prawns had a faster time to lethargy than the females (Tukey, $p<0.05$ ). The latest lethargy time in both males and females was related to the $\mathrm{AX}_{150}$ diet (Table 6). Although the male prawns died later than the females, there were no significant differences (Tukey, $\mathrm{p}>0.05$ ), between the average time to complete death of male and female prawns under hypo-oxygen shock. The latest complete death in both males and females was observed with the $\mathrm{AX}_{100}$ diet, and the fastest time to complete death in both males and females was observed with the control diet (Table 6). There were no significant differences (Tukey, $\mathrm{p}>0.05$ ) in the reduction of the total carotenoid level in the muscle tissue of male and female prawns (Table 6). The highest percentage reduction in carotenoids in muscle tissue was observed with the $\mathrm{AX}_{150}$ diet (Table 6). The greatest reduction in carotenoids

TABLE 5

Average time of lethargy, complete death, and loss percentage of total carotenoid in gill and muscle tissues against ammonia shock in M. nipponense

\begin{tabular}{|c|c|c|c|c|c|}
\hline \multicolumn{2}{|c|}{$\begin{array}{c}\text { Treatment } \\
\text { (Astaxanthin kg Dried diet) }\end{array}$} & Lethargy (h) & Death (h) & $\begin{array}{l}\text { Loss percentage } \\
\text { muscle tissue carotenoid }\end{array}$ & $\begin{array}{l}\text { Loss percentage gill } \\
\text { carotenoid }\end{array}$ \\
\hline \multicolumn{2}{|r|}{$\mathrm{AX}_{0}$} & $9.1 \pm 0.3^{\mathrm{c}}$ & $13.3 \pm 0.3^{\mathrm{c}}$ & $31.5 \pm 0.95^{\mathrm{c}}$ & $54.06 \pm 0.3^{\mathrm{d}}$ \\
\hline \multicolumn{2}{|r|}{$\mathrm{AX}_{50}$} & $9.3 \pm 0.3^{\mathrm{c}}$ & $14.8 \pm 0.3^{\mathrm{b}}$ & $55.7 \pm 0.98^{\mathrm{b}}$ & $49.31 \pm 0.5^{\mathrm{c}}$ \\
\hline \multicolumn{2}{|r|}{$\mathrm{AX}_{100}$} & $11.3 \pm 0.2^{\mathrm{b}}$ & $19.5 \pm 0.4^{\mathrm{a}}$ & $59.2 \pm 1.26^{\mathrm{a}}$ & $63.34 \pm 0.4^{\mathrm{b}}$ \\
\hline \multicolumn{2}{|r|}{$\mathrm{AX}_{150}$} & $14.5 \pm 0.5^{\mathrm{a}}$ & $18.8 \pm 0.5^{\mathrm{a}}$ & $60.2 \pm 1.24^{\mathrm{a}}$ & $68.49 \pm 0.3^{\mathrm{a}}$ \\
\hline \multicolumn{2}{|r|}{ Male } & $8.9 \pm 0.1^{\mathrm{a}}$ & $13.9 \pm 0.3^{b}$ & $53.4 \pm 0.86^{\mathrm{a}}$ & $62.28 \pm 0.2^{\mathrm{a}}$ \\
\hline \multicolumn{2}{|r|}{ Female } & $11.1 \pm 0.3^{\mathrm{b}}$ & $19.3 \pm 0.3^{\mathrm{a}}$ & $49.9 \pm 0.75^{b}$ & $55.32 \pm 0.2^{\mathrm{b}}$ \\
\hline \multirow{4}{*}{$\frac{0}{\sum^{\pi}}$} & $\mathrm{AX}_{0}$ & $7.6 \pm 0.4^{b}$ & $10.2 \pm 0.4^{\mathrm{c}}$ & $28.5 \pm 0.2^{\mathrm{d}}$ & $57.6 \pm 0.56^{\mathrm{d}}$ \\
\hline & $\mathrm{AX}_{50}$ & $7.3 \pm 0.4^{b}$ & $12.2 \pm 0.4^{\mathrm{b}}$ & $56.0 \pm 0.4^{\mathrm{c}}$ & $57.2 \pm 0.5^{\mathrm{c}}$ \\
\hline & $\mathrm{AX}_{100}$ & $9.3 \pm 1.3^{\mathrm{a}}$ & $16.8 \pm 0.5^{\mathrm{a}}$ & $62.6 \pm 0.3^{b}$ & $65.8 \pm 0.4^{\mathrm{b}}$ \\
\hline & $\mathrm{AX}_{150}$ & $17.5 \pm 0.9^{\mathrm{a}}$ & $16.3 \pm 0.5^{\mathrm{a}}$ & $66.4 \pm 0.5^{\mathrm{a}}$ & $71.4 \pm 0.3^{\mathrm{a}}$ \\
\hline \multirow{4}{*}{$\begin{array}{l}\frac{0}{\tilde{J}} \\
\text { ]ี } \\
\end{array}$} & $\mathrm{AX}_{0}$ & $10.6 \pm 0.4^{\mathrm{c}}$ & $16.4 \pm 0.4^{\mathrm{b}}$ & $34.5 \pm 0.1^{b}$ & $53.6 \pm 0.5^{\mathrm{d}}$ \\
\hline & $\mathrm{AX}_{50}$ & $11.2 \pm 0.9^{c}$ & $17.3 \pm 0.4^{\mathrm{b}}$ & $55.4 \pm 0.2^{\mathrm{a}}$ & $41.4 \pm 0.5^{\mathrm{c}}$ \\
\hline & $\mathrm{AX}_{100}$ & $13.3 \pm 1.3^{\mathrm{b}}$ & $22.2 \pm 0.5^{\mathrm{a}}$ & $55.7 \pm 0.3^{\mathrm{a}}$ & $60.8 \pm 0.4^{\mathrm{b}}$ \\
\hline & $\mathrm{AX}_{150}$ & $17.5 \pm 0.9^{\mathrm{a}}$ & $21.4 \pm 0.4^{\mathrm{a}}$ & $53.9 \pm 0.4^{\mathrm{a}}$ & $65.5 \pm 0.3^{\mathrm{a}}$ \\
\hline
\end{tabular}

$*(\% ; \pm$ standard error $)$. Means in each semi-column followed by the same letters are not significantly different at $\mathrm{p}<0.05$. 
TABLE 6

Average time of lethargy, complete death, and loss percentage of total carotenoid in gill and muscle tissues against hypoxygen shock in M. niponnense*

\begin{tabular}{|c|c|c|c|c|c|}
\hline \multicolumn{2}{|c|}{$\begin{array}{c}\text { Treatment } \\
\text { (Astaxanthin kg Dried diet) }\end{array}$} & Lethargy (hr) & Death (hr) & $\begin{array}{l}\text { Loss percentage of body } \\
\text { carotenoid }\end{array}$ & $\begin{array}{l}\text { Loss percentage of gill } \\
\text { carotenoid }\end{array}$ \\
\hline \multicolumn{2}{|c|}{$\mathrm{AX}_{0}$} & $1.3 \pm 0.2^{b}$ & $2.2 \pm 0.1^{\mathrm{c}}$ & $24.6 \pm 0.7^{\mathrm{d}}$ & $48.8 \pm 1.5^{\mathrm{d}}$ \\
\hline \multicolumn{2}{|r|}{$\mathrm{AX}_{50}$} & $1.2 \pm 0.1^{\mathrm{b}}$ & $2.9 \pm 0.2^{\mathrm{b}}$ & $42.6 \pm 0.9^{\mathrm{c}}$ & $56.8 \pm 1.3^{\mathrm{c}}$ \\
\hline \multicolumn{2}{|r|}{$\mathrm{AX}_{100}$} & $1.4 \pm 0.2^{b}$ & $3.3 \pm 0.1^{\mathrm{a}}$ & $50.3 \pm 0.9^{\mathrm{b}}$ & $61.9 \pm 4.2^{\mathrm{b}}$ \\
\hline \multicolumn{2}{|r|}{$\mathrm{AX}_{150}$} & $1.7 \pm 0.1^{\mathrm{a}}$ & $3.2 \pm 0.1^{\mathrm{a}}$ & $59.4 \pm 0.8^{\mathrm{a}}$ & $67.5 \pm 1.2^{\mathrm{a}}$ \\
\hline \multicolumn{2}{|r|}{ Male } & $1.2 \pm 0.1^{\mathrm{b}}$ & $3.0 \pm 0.1^{\mathrm{a}}$ & $44.9 \pm 0.7^{\mathrm{a}}$ & $60.9 \pm 0.7^{\mathrm{a}}$ \\
\hline \multicolumn{2}{|r|}{ Female } & $1.6 \pm 0.1^{\mathrm{a}}$ & $2.9 \pm 0.1^{\mathrm{a}}$ & $43.6 \pm 0.9^{\mathrm{a}}$ & $56.6 \pm 0.7^{\mathrm{b}}$ \\
\hline \multirow{4}{*}{$\sum_{i}^{\frac{0}{\pi}}$} & $\mathrm{AX}_{0}$ & $1.2 \pm 0.1^{\mathrm{b}}$ & $2.3 \pm 0.2^{\mathrm{b}}$ & $25.5 \pm 0.3^{\mathrm{d}}$ & $50.04 \pm 1.5^{\mathrm{c}}$ \\
\hline & $\mathrm{AX}_{50}$ & $1.1 \pm 0.1^{\mathrm{ab}}$ & $3.2 \pm 0.1^{\mathrm{a}}$ & $36.1 \pm 0.4^{\mathrm{c}}$ & $60.9 \pm 1.2^{\mathrm{b}}$ \\
\hline & $\mathrm{AX}_{100}$ & $1.3 \pm 0.1^{\mathrm{a}}$ & $3.3 \pm 0.1^{\mathrm{a}}$ & $55.8 \pm 0.3^{b}$ & $63.0 \pm 1.4^{\mathrm{b}}$ \\
\hline & $\mathrm{AX}_{150}$ & $1.3 \pm 0.1^{\mathrm{a}}$ & $3.1 \pm 0.2^{\mathrm{a}}$ & $63.9 \pm 0.2^{\mathrm{a}}$ & $69.6 \pm 1.4^{\mathrm{a}}$ \\
\hline \multirow{4}{*}{ 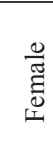 } & $\mathrm{AX}_{0}$ & $1.3 \pm 0.0^{\mathrm{b}}$ & $2.1 \pm 0.1^{\mathrm{c}}$ & $36.1 \pm 0.2^{\mathrm{a}}$ & $47.5 \pm 1.1^{b}$ \\
\hline & $\mathrm{AX}_{50}$ & $1.2 \pm 0.1^{\mathrm{b}}$ & $2.5 \pm 0.1^{\mathrm{b}}$ & $49.2 \pm 0.3^{\mathrm{a}}$ & $52.6 \pm 1.1^{\mathrm{b}}$ \\
\hline & $\mathrm{AX}_{100}$ & $1.6 \pm 0.1^{\mathrm{ab}}$ & $3.5 \pm 0.1^{\mathrm{a}}$ & $44.8 \pm 0.4^{\mathrm{a}}$ & $60.7 \pm 1.2^{\mathrm{a}}$ \\
\hline & $\mathrm{AX}_{150}$ & $2.1 \pm 0.1^{\mathrm{a}}$ & $3.4 \pm 0.1^{\mathrm{a}}$ & $54.8 \pm 0.3^{\mathrm{a}}$ & $65.3 \pm 1.5^{\mathrm{a}}$ \\
\hline
\end{tabular}

$*(\% ; \pm$ standard error $)$; Means in each semi-column followed by the same letters are not significantly different at $\mathrm{p}<0.05$.

in male and female shrimp gills was observed with the $\mathrm{AX}_{150}$ diet, and the lowest reduction was observed with the control diet (Table 6).

\section{DISCUSSION}

Research has shown that carotenoids positively affect shrimp survival under stress conditions; this has been supported by the studies of Chien et al. (2003). The current study revealed that the absorption rate of carotenoids in the gills and muscle tissues of male and female $M$. nipponense prawn was not significantly different after the shrimp consumed foods containing astaxanthin for two weeks.

It has been reported that resistance of juvenile shrimp to thermal stress increases with increased amounts of astaxanthin in the diet. The current study has shown that with an increase in astaxanthin in the diet, the mean time to lethargy and death in prawns is increased, and prawn that received more astaxanthin during their growing period had longer time-to-lethargy and time-to-death periods during the shock treatments. An increase in astaxanthin in the diet from $100 \mathrm{mg} / \mathrm{kg}$ to $150 \mathrm{mg} /$ $\mathrm{kg}$ had no effect on the increased resistance to thermal shock. Most likely, an increase in astaxanthin in the diet will be accompanied by a decrease in intestinal absorption (Stanier et al., 1971).

Male prawns showed greater resistance against thermal shock. This result most likely occurred because males have a harder shell than females, which offers greater resistance. Due to thermal shock, the amount of carotenoids in muscle tissue and gills was considerably decreased. The reduction in the muscle tissue and gills was not significantly different (Tukey, $\mathrm{p}>0.05$ ) between males and females. This decrease is most likely due to the direct effects of carotenoids in muscle tissues and gills under conditions of thermal stress (WanYu, Kuan-Fu, I-Chiu, \& Yen-Ling, 2004).

The greatest carotenoid reduction in muscle tissue and gills was observed in prawn fed the $\mathrm{AX}_{100}$ and $\mathrm{AX}_{150}$ diets. This result may be due to the higher amounts of carotenoids in the muscle tissues and gills of prawns fed these two diets at the time that thermal shock began. When the amount of carotenoids in muscle tissues and gills at the beginning of the shock 
period is higher, the loss will be greater during the time that the prawns are exposed to more stressful conditions.

Our observations have shown that the average time to lethargy and complete death under thermal shock was greater in prawns fed diets containing astaxanthin versus control prawns. These results indicate that astaxanthin, as one of the carotenoids, has increased the resistance of the tested prawns against thermal shock, and prawns demonstrated increased resistance against thermal shock when they were fed diets containing astaxanthin (Frankenberg, Jackson, \& Clegg, 2000). While prawns fed astaxanthin took longer to become lethargic (faint), they died much sooner than the control shrimp.

Ammonia is known to be toxic to aquatic animals (Kinne, 1976). As it penetrates cell membranes, ammonia causes severe changes in cells, leading to rapid cell death (Becker, 2011). An increase in the amount of ammonia in the water, followed by an increase in the blood and hemolymph of prawns, will decrease blood oxygen transport and lead to over-consumption of oxygen in the cells, which causes damage to important tissues, including the gills. If prawns remain in an environment containing ammonia, they may experience a quick death depending on the ammonia concentration (Tomasso, 1994).

This study has shown that prawns exposed to different treatments under $0.75 \mathrm{ml} / \mathrm{L}$ ammonia, control prawns, and prawns fed an $\mathrm{AX}_{50}$ diet, showed lethargy earlier than prawns exposed to the other two treatments; however, the time to complete death of control prawns was faster than that of prawns exposed to the other treatments.

These results have shown that during exposure to toxic ammonia and cellular oxygen loss (Sies, 1991), astaxanthin in the gills and muscles of prawn fed with a control diet could cause the accumulation of intracellular oxygen radicals due to oxygen-induced reactions with the long carbon chains. As a result, the damage caused by oxygen free radicals in the cells of significant tissues (such as the gills, kidneys, and muscles) is reduced, and prawn mortality is delayed.

Storey (1996) reported that ammonia poisoning is usually associated with a lack of access to dissolved oxygen, and this usually leads to oxidative stress. In aquaculture, ammonia is absorbed through the gills and skin into the blood and hemolymph (Chen, Nan, \& Kuo, 1991). Therefore, if the animal's body surface area is larger, an increase in ammonia absorption will occur (Vedel, Korsgaard, \& Jensen, 1998). This phenomenon may have caused the faster mortality of male versus female prawns. Because the male prawns were larger than the females, the time to lethargy and complete death occurred faster in male prawns compared with females. The same phenomenon caused males to lose more carotenoids in ammonia shock compared with females. This effect was evidenced by the reduction in the amount of carotenoids in muscle and gill tissues of males compared with females.

In gills, the percentage reduction in carotenoids in the tissue was significantly different between the $\mathrm{AX}_{150}$ and $\mathrm{AX}_{100}$ diets, with the gill tissue in shrimp fed the $\mathrm{AX}_{150}$ diet showing a greater loss compared with gill tissue in prawn fed the $\mathrm{AX}_{100}$ diet after the shock. Given that the target tissue of ammonia is the gill tissue, the carotenoid reduction in the gill tissue of the shrimp fed the $\mathrm{AX}_{150}$ diet was greater than that observed with the other treatments. It is possible that reduced levels of carotenoids in this tissue indicate that more carotenoids were used to counteract the toxic effects of ammonia.

Studies have shown that diets containing carotenoids can increase the resistance of crustaceans (Chien et al., 1999). Chien et al. (2003) showed that shrimp fed diets containing astaxanthin showed less oxygen consumption than control shrimp under hypoxia. A similar result was obtained by Chien et al. (1999) using the shrimp Penaeus monodon.

It is possible that astaxanthin, similar to other carotenoids containing oxygen such as lutein (Czeczuga, 1979), may also have oxygen attached to the carbon chain (Karnaukhov, 1979) and may provide an intracellular oxygen 
supply to salmon eggs that are exposed to oxygen deficiency (Craik,1985). Such intracellular oxygen reserves or oxygen acceptors may be involved in the resistance of aquatic organisms to hypoxia (Latscha, 1990; Oshima, Ojima, Sokamoto, Ishiguro, \& Terao, 1993).

This increases the resistance of crustaceans to hypoxia (Chien \& Jeng, 1992). The main carotenoid in the crustacean body is astaxanthin (Ishikawa, Miyake, \& Yasuie, 1966; Arredondo-Figueroa, Pedroza-Islas, Ponce-Palafox, \& Vernon-Carter, 2003; Ponce-Palafox et al., 2006). The shrimp Kuruma (M. japonicus), which has a high level of astaxanthin in its tissues, can tolerate hypoxic conditions without water transportation (Baileg-Broch \& Moss, 1992). This study has shown that prawn fed with $\mathrm{AX}_{150}$ diets, which was the highest astaxanthin level used in this study, spent a significantly longer period of time under hypoxic conditions prior to reaching a state of lethargy. This group, along with prawns fed an $\mathrm{AX}_{100}$ diet, later showed complete death.

The results of this study have shown that the amount of muscle tissue and gill carotenoids in prawn fed with an $\mathrm{AX}_{150}$ diet showed greater reduction than those exposed to other treatments. It is possible that higher levels of astaxanthin in the body under oxygen reduction stress can be beneficial for prawns. These results suggest that male prawns showed lethargy earlier than females, and the percentage of carotenoid reduction in muscle and gill tissues was higher in males.

\section{ACKNOWLEDGMENTS}

This experiment was conducted based on the support of Jehade-E-Agriculture Ministry, Iran and also Mirza Koochak Khan Higher Fisheries Center, University of Jame-e ElmiKarbordi, Rasht, Iran.

\section{RESUMEN}

Efecto de la astaxantina en la resistencia al estrés físico y químico de los langostinos jóvenes de Macrobrachium nipponense (Decapoda: Palaemonidae). En años recientes, la utilización de nuevas técnicas científicas ha tenido un efecto importante en mejorar los procesos de producción en acuicultura. La astaxantina tiene varias propiedades en la acuicultura y sus propiedades antioxidantes se encuentran estrechamente relacionadas con la resistencia al estrés. La astaxantina en muchos crustáceos y peces es un factor esencial para el crecimiento. El objetivo de este estudio fue evaluar la resistencia del langostino (Macrobrachium nipponense) alimentado con dietas conteniendo diferentes cantidades de astaxantina (AX), bajo diferentes condiciones de estrés ambiental. Un ensayo de 70 días fue llevado a cabo para evaluar el efecto de la suplementación de fuentes de astaxantina (Carophyll Pink, $10 \%$ astaxanthin) en varios niveles en la dieta de jóvenes de $M$. nipponense. Cuatro dietas fueron preparadas: $\mathrm{AX}_{0}$ sin astaxantina, $\mathrm{AX}_{50}$ con $50 \mathrm{mg} / \mathrm{kg}, \mathrm{AX}_{100}$ con $100 \mathrm{mg} / \mathrm{kg}$ y AX $\mathrm{AX}_{150}$ con $150 \mathrm{mg} / \mathrm{kg}$ de astaxantina. Los ensayos de alimentación fueron conducidos en un sistema de recirculación de agua consistente en 12 estanques de fibra de vidrio (1 000L). Tres replicas fueron sembradas con $360 r g / \mathrm{m}^{2}$ por tanque. Durante el experimento los langostinos fueron mantenidos con un fotoperiodo de 12:12 luz:oscuridad con lámparas incandescentes y los parámetros de la calidad del agua fueron mantenidos a $25-26^{\circ} \mathrm{C}$ la temperatura, $1 \mathrm{~g} / \mathrm{L}$ la salinidad, 8.5-8.8 el pH, 6.0-6.5 mg/L el oxígeno y $0.05 \mathrm{mg} / \mathrm{L}$ el nitrógeno amoniacal. La incorporación de la astaxantina, producción y condiciones fisicoquímicas fueron registradas después de 10 semanas de alimentación. Al final del periodo de crecimiento, los langostinos fueron expuestos a un shock térmico $\left(0^{\circ} \mathrm{C}\right)$, amonio $(0.75 \mathrm{mg} / \mathrm{L})$ y reducción de oxígeno $0.5 \mathrm{mg} / \mathrm{L}$. El tiempo de letargia y el tiempo de muerte fueron registrados. Se encontró que la dieta con la mayor concentración de astaxantina $(150 \mathrm{mg} / \mathrm{kg})$ presentó el mayor tiempo de letargia y la mayor concentración en branquias y músculo en el langostino $M$. nipponense.

Palabras clave: amonio, astaxantina, estrés, langostino, termal.

\section{REFERENCES}

Aispuro-Hernandez, E., Garcia-Orozco, K. D., MuhliaAlmazan, A., Del-Toro-Sánchez, L., Robles-Sánchez, R. M., Hernández, J., González-Aguilar, G., YepizPlascencia, G., \& Sotelo-Mundo, R. R. (2008). Shrimp thioredoxin is a potent antioxidant protein. Comparative Biochemistry and Physiology C-Pharmacology Toxicology and Endocrinology, 148, 94-99.

Association of Analytical Chemists [AOAC]. (2005). Official Methods of Analysis (18th Ed.). Gaithersburg, Maryland.

Arredondo-Figueroa, J. L, Pedroza-Islas, R., Ponce-Palafox, J. T., \& Vernon-Carter, J. E. (2003). Pigmentation of pacific white shrimp (Litopenaeus vannamei, BOONE 1931) with esterified and saponified carotenoids from red chile (Capsicum annuum) 
in comparison to astaxanthin. Revista Mexicana de Ingeniería Química, 2, 101-108.

Bailey-Brock, J. H., \& Moss, S. M. (1992). Penaeid taxonomy, biology and zoogeography. In A. W. Fast, \& L. J. Lester (Eds.), Marine Shrimp Culture: Principles and Practices (pp. 9-27). Amsterdam, The Netherlands: Elsevier Science Publishers B.V.

Becker, A. (2011). The involvement of aquaporins in Ammonia /Ammonium Transport Across Root Cell Membranes of Barley (Hordeum vulgare L.) (Master of Science's thesis). University of Toronto, Canada.

Buchwaldt, M., \& Jencks, W. P. (1968). Optical properties of astaxanthin solutions and aggregates. Biochemistry, 7(2), 834-843.

Chen, J. C., Nan, F. H., \& Kuo, C. M. (1991). Oxygen consumption and ammonia-N excretion of prawns (Penaeus chinensis) exposed to ambient ammonia. Archives of Environmental Contamination and Toxicology, 21, 377-382.

Chew, B. P. (1995). Antioxidant vitamins affect food animal immunity and health. Journal of Nutrition, 125, 1804S-1808S. Retrieved from http://jn.nutrition.org/ content/125/6_Suppl/ 1804S.full.pdf

Chien, Y. H., \& Jeng, S. C. (1992). Pigmentation of kuruma prawn, Penaeus japonicus Bate, by various pigment sources and levels and feeding regimes. Aquaculture, 102, 333-346.

Chien, Y. H., Chen, I. M., Pan, C. H., \& Kurmaly, K. (1999). Oxygen depletion stress on mortality and lethal course of juvenile tiger prawn Penaeus monodon fed high level of dietary astaxanthin. Journal of the Fisheries Society of Taiwan, 26, 85-93. Retrieved from http:// eurekamag.com/research/003/517/oxygen-depletionstress-mortality-lethal-juvenile-tiger-prawn-penaeusmonodon-fed-high-degree-dietary-astaxanthin.php

Chien, Y. H., Pan, C. H., \& Hunter, B. (2003). The resistance to physical stresses by Penaeus monodon juveniles fed diets supplemented with astaxanthin. Aquaculture, 216, 177-191.

Craik, J. C., \& Harvey, S. M. (1984). Egg quality in rainbow trout: the relation between egg viability, selected aspects of egg composition, and time of stripping. Aquaculture, 40, 115-134.

Craik, J. C. A. (1985). Egg quality and egg pigment content in salmonid fishes. Aquaculture, 47, 61-88.

Czeczuga, B. (1979). Carotenoids in fish: XIX. Carotenoids I the eggs of Oncorhynchus keta. Hydrobiologia, 63, 45-47.

Darachai, J., Piyatiratitivorakul, S., Kittakoop, P., Nitithamyong, C., \& Menasveta, P. (1998). Effects of Astaxanthin on larval growth and survival of the giant tiger prawn, Penaeus monodon. In T. W. Flegel (Ed.), Advances in Shrimp Biotechnology (p. 117-121).
Bangkok: National Center for Genetic Engineering and Biotechnology.

Frankenberg, M. M., Jackson, J. S., \& Clegg, J. S. (2000). The heat shock response of adult Artemia franciscana. Journal of Thermal Biology, 25, 481-490.

Hornero-Mendez, D., \& Britton, G. (2002). Involvement of NADPH in the cyclization reaction of carotenoid biosynthesis. FEBS Lett, 515, 133-136.

Ishikawa, W., Miyake, Y., \& Yasuie, S. (1966). Chromatophores and carotenoids in cultured kuruma-prawn, Penaeus japonicus Bate, of different body colours. Bulletin Fisheries Experimental Station, 5, 18-24.

Karnaukhov, V. N. (1979). The role of filtrator mollusks rich in carotenoid in the self-cleaning of fresh waters. Symposium Biologica Hungarica, 19, 151-167.

Kinne, O. (1976). Cultivation of marine organisms: water quality management and technology. In O. Kinne (Ed.), Marine Ecology (Vol. III, part 1, pp. 79-300). New York: Wiley-Interscience.

Latscha, T. (1990). Carotenoids in animal nutrition: their nature and significance in animal feeds. In Animal Nutrition and Health. Roche publication no. 2175. Basel, Switzerland: F. Hoffmann-La Roche.

Merchie, G., Kontara, E., Lavens, P., Robles, R., Kurmaly, K., \& Sorgeloos, P. (1998). Effect of vitamin C and astaxanthin on stress and disease resistance of postlarval tiger shrimp Penaeus monodon (Fabricius). Aquaculture Research, 29, 579-585.

Miki, W. (1991). Biological functions and activities of animal carotenoids. Pure and Applied Chemistry, 63, 141-146.

Montgomery, D. C. (2005). Diseño y Analisis de Experimentos [Design and Analysis of Experiments]. Mexico: Limusa Wiley.

Oshima, S., Ojima, F., Sokamoto, H., Ishiguro, Y., \& Terao, J. (1993). Inhibitory effect of h-carotene and astaxanthin on photosynthesized oxidation of phospholipid bilayers. Journal of Nutritional Science and Vitaminology, 39, 607-615.

Pan, C. H., Chien, Y. H., \& Hunter, B. (2003). The resistance to ammonia stress of Penaeus monodon Fabricius juvenile fed diets supplemented with astaxanthin. Journal of Experimental Marine Biology and Ecology, 297, 107-118.

Ponce-Palafox, J. T., Arredondo-Figueroa, J. L., \& VernonCarter, E. J. (2006). Carotenoids from plants used in diets for the culture of the pacific white shrimp (Litopenaeus vannamei). Revista Mexicana de Ingeniería Química, 5(2), 157-165. Retrieved from http://www. redalyc.org/pdf/620/62050206.pdf

Schoefs, B. (2002). Chlorophyll and carotenoid analysis in food products. Properties of the pigments and methods of analysis. Trends in Food Science \& Technology, 13(11), 361-371. 
Shimidzu, N., Goto, M., \& Miki, W. (1996). Carotenoids as singlet oxygen quenchers in marine organisms. Fisheries Science, 62, 134-137. Retrieved from https://www.jstage.jst.go.jp/article/ fishsci1994/62/1/62_1_134/_pdf

Sies, H. (1991). Oxidative stress: from basic research to clinical application. American Journal of Medicine, 91(3C), 31S- 38S.

Stanier, R. Y., Kunizawa, M. M., \& Cohen-Bazire, G. (1971). Purification and property of unicellular blue-green algae (Order Chroococales). Archive of Bacteriological Reviews, 35, 120-171. Retrieved from http://www.ncbi.nlm.nih.gov/pmc/articles/ PMC378380/?page $=1$

Storey, K. B. (1996). Oxidative stress: animal adaptations in nature. Brazilian Journal of Medical and Biological Research, 29, 1715-1733. Retrieved from http:// www.ncbi.nlm.nih.gov/pubmed/9222437

Tomasso, J. R. (1994). Toxicity of nitrogenous wastes to aquaculture animals. Reviews in Fisheries Science, 2, 291-314.

Torrissen, O. J., \& Christiansen, R. (1995). Requirements for carotenoids in fish diets. Journal of Applied Ichthyology, 11, 225-230.
Torrissen, O. J. (1990). Biological activities of carotenoids in fishes. The current status of fish nutrients in aquaculture. In M. Takeda, \& T. Watanabe (Eds.), Proceedings of the Third International Symposium on Feeding and Nutrition in Fish (pp. 387- 399). Tokyo, Japan: Tokyo University of Fisheries.

Vedel, N. E., Korsgaard, B., \& Jensen, F. B. (1998). Isolated and combined exposure to ammonia and nitrite in rainbow trout (Oncorhynchus mykiss): effects electrolyte status, blood respiratory properties and brain glutamine/glutamate concentration. Aquatic Toxicology, 41, 325-342.

Wan-Yu, L., Kuan-Fu, L., I-Chiu, L., \& Yen-Ling, S. (2004). Cloning and molecular characterization of heat shock cognate 70 from tiger shrimp (Penaeus monodon). Cell Stress Chaperon, 9, 332-343.

Yarzhombek, A. A. (1970). The carotenoids of salmonidae and their connection with the reproduction of these fishes. Trudy VNIRO, 59, 25-32.

Yuan, J. P., Peng, J., Yin, K., \& Wang, J. H. (2011). Potential health-promoting effects of astaxanthin: A highvalue carotenoid mostly from microalgae. Molecular Nutrition \& Food Research, 55, 150-165. 
